\title{
How to Be a Serious Leisure Participant? (A Case Study)
}

\author{
Utku Isik \\ Correspondence: School of Physical Education and Sports, Recep Tayyip Erdogan University, Rize, Turkey.
}

Received: July 11, 2018

doi:10.11114/jets.v6i9.3453
Accepted: August 5, $2018 \quad$ Online Published: August 6, 2018

URL: https://doi.org/10.11114/jets.v6i9.3453

\begin{abstract}
The benefits of serious leisure activities demonstrate the significance of serious leisure participation. This study is thought to contribute to literature on how leisure time participation can be generated and sustained. This research presents a case study analysis on how an individual can be a significant leisure participant. In line with the purpose of the study, an "Astro pitch" organization was done which was originally started by the researcher but later continued by participants themselves willingly without any intervention. This organization continued on Mondays and a total of 14 participants (7 in each team) participated in the activity for about 8 months. Semi-structured interview technique (a qualitative technique) was used during data collection. While the games continued (they are still going on), the participants were first informed about serious leisure activities and they were asked whether this organization was considered as a serious leisure activity by them. Later, the researcher prepared a theoretical framework to ask participants how the organization was born, how it continued non-stop with the same participants and the general benefits of this organization. The main ideas obtained by the researcher were analyzed in terms of content by using Maxqda program and codes, categories and themes were obtained. According to themes found in this study; a leader is required for the participants to be a serious leisure participants and to sustain the activity; the activity should include opportunities for the individual to stand out, there must be rapport in the group, and the activity should be enjoyed.
\end{abstract}

Keywords: serious leisure, leisure participant, recreation, group activity

\section{Introduction}

Throughout history, scientists in many fields have been concerned about how mankind spends their leisure time. It is observed in human history that leisure activities are generally carried out to sustain life. Based on historical monuments, excavation sites, cave paintings and from the relics, Hamilton-Smith (1993) indicate that archeological findings in regards to leisure time date back to prehistoric cultures. According to McBrearty \& Stringer (2007), people today demonstrate their social status and group identity with visual clues such as apparel, jewelry, cosmetics and hairstyle and these behaviors are similar to those of people who dyed their clothes and bodies with ochre 80,000 years ago in North and South Africa. Societies have changed over time and so have individuals' concepts of work and leisure. Slyvester (1999) stated that leisure time belonged only to the elite during the classical Greek era. Aristotle regarded the concept of work as "rape of a good life". According to Aristotle, people can make their lives better only when they are protected from having to work for their vital needs. Moreover, leisure time, which meant "not working" in Ancient Greece, was a condition for a good life. Based on these; Aristotle stated that happiness depended on leisure. As a matter of fact, what today's researchers defend in contemporary world is not that different than the opinions Aristotle presented thousands of years ago. The only difference is the change in the meaning of leisure time from one day to another; primarily based on advances in technology and life. While hunting and gathering were vital activities for the vast majority of the population to survive in the past; today hunting and gathering are areas where only a few people are involved in to make their living. Moreover, today, hunting is a popular leisure time activity for some people. While music, dance and sports activities are leisure activities for some, others take up these activities professionally and make money from them. However, it should be noted that individuals who take up these activities professionally also need leisure time and leisure time activities. As individuals begin to participate in leisure activities, they become so involved in them that these activities become a part of their personality and they may choose to become professionals in these areas. Godbout (1990) referred to this as the professionalization of leisure activities. The idea of professionalization of leisure activities has brought a fresh perspective to leisure studies: serious leisure perspective.

Stebbins (1997), who first introduced this concept and conducted etrographic studies on the subject for a long time, defined serious leisure as: "the systematic pursuit of an amateur, hobbyist, or volunteer core activity that is highly 
substantial, interesting, and fulfilling and where, in the typical case, participants find a career in acquiring and expressing a combination of its special skills, knowledge, and experience (Akyildiz, 2013; Flack, 2006; Stebbins, 1997; Stebbins, 2012a; Shen \& Yarnal, 2010). However, when Stebbins defined serious leisure time, he stated that serious leisure did not fit into the definition of leisure time and that serious leisure participants participated in deeper contextual and recreational activities. Also in an another definition, serious leisure is defined as an amateur, hobby, or voluntary activity that requires specific knowledge, skill and experience and which is quite important, interesting and satisfactory in order to get a career" (Akyildiz, 2013; Flack, 2006; Stebbins, 1997; Stebbins, 2012a; Shen \& Yarnal, 2010; Kim, Dattilo, \& Heo, 2011; Barbieri \& Sotomayor, 2013).

Stebbins $(1980,1993,1997,2012 b)$ examined the nature of serious leisure with interdisciplinary comparative studies over 30 years. As a result of these studies, Stebbins identified six distinct characteristics that distinguished serious leisure participants from casual leisure participants. Accordingly, serious leisure participants;

- Persist in the activity carried out at leisure time (they are determined),

- Make personal and worthwhile efforts,

- Want to obtain leisure time careers,

- Get concrete and continuous benefits,

- Try to create a social world composed of authentic norms, beliefs or values and become members of this social community,

- Form strong bonds with the selected activity (Akyildiz, 2013; Flack, 2006; Stebbins, 1997; Stebbins, 2012a; Shen \& Yarnal, 2010).

When these characteristics are examined; it can be argued that the serious leisure participants are committed to selected leisure activities to an extent that can influence their lives, they change their daily lives around these activities and place these activities in the center of their lives. If the person has the characteristics described above for a specific activity, it can be argued that he/she is now a serious leisure activity participant. Being a leisure time participant provides significant benefits to the individual in every sense (Patterson, 2000, 2001; Aitchison, 2003; Kleiber, 1999; Roker, Player, \& Coleman, 1998, Patterson \& Pegg; 2009). Stebbins (2009) advocated that serious leisure activities provide individuals with social interaction, feelings related to group success and feelings of contribution to the development of the group in addition to personal benefits such as personal empowerment, self-realization, self-expression, self-awareness, satisfaction, pleasure, enjoyment and financial return. Leisure activities have benefits to individuals in general but serious leisure activities provide more serious benefits and the underlying cause for this difference lies in the basic features that distinguish casual leisure time from serious leisure time.

As the benefits of serious leisure activities were better comprehended by researchers, more studies have been conducted to investigate the types of serious leisure activities and their benefits. Literature review points to studies on serious leisure activities in the field of tourism (Wearing, 2004; Harrison, 2001; Weiler \& Hall, 1992), quality of life and well-being (Haworth, 1986; Mannell,1993), leisure education (Stebbins, 2001; Hutchinson \& Kleiber, 2005), retirement and unemployment (Stebbins, 2005; Heuser, 2005; Roberson, 2005) and disabilites (Kleiber,1999; Patterson, 2000; Isik, 2017). However, these studies have focused on individuals with significant leisure time participation and they have not examined the process of involvement in serious leisure time activities. The factors affecting individuals' involvement in serious leisure activities when these persons have had no previous experience of leisure time activity have not been examined much.

The benefits of serious leisure activities demonstrate the significance of serious leisure participation. This study is thought to contribute to literature on how leisure time participation can be generated and sustained. This research presents a case study analysis on how an individual can be a significant leisure participant.

\section{Method}

\subsection{Procedure}

In line with the purpose of the study, an "Astro pitch" organization was done which was originally started by the researcher but later continued by participants themselves willingly without any intervention. The first two weeks, the fees for the organization were paid by the researcher and after two weeks, the participants continued the contests on their won and the losing party paid the fees for the pitch. If there were no interest on the part of the participants to carry out the organization after two weeks, the study was going to be terminated at this point but participants wanted to continue the football games. This organization continued on Mondays and a total of 14 participants ( 7 in each team) participated in the activity for about 8 months. Participants were not given any information about the study when the football games started. They were only asked whether they wanted to participate in the games in the astro pitch whose fees for the past two weeks had been paid. 
Throughout the games, the researcher observed the general behavior of the participants and was careful not to attend all the games so as not to attract attention. The role of the researcher was limited to observation and he did not intervene in any way. While there was no competitiveness during the first few games, the teams designed custom jerseys for the games without any intervention from the researcher. By time, the teams created social media profiles on Instagram and Facebook and evaluated the scores with the other team players after the games and sometimes made fun of the members of the opponent team. As time went by, they developed techniques and tactics and evaluated each game afterwards. By time, the teams tried to take the games rather seriously. They named their teams (The LosGalacticos and The Avangeres) and designed jerseys for their teams. Members of each team posted fun comments on social media after each game based on the score of that week's game. In short, the games started to be a part of their lives and the members began to demonstrate the characteristics of serious leisure time participation. At this point, the study was redesigned by the researcher.

\subsection{Participants}

The participants were selected by the researcher from a group of 32 individuals who played amateur football. The formation of this group was not based on any criteria; the researcher knew the participants from the classes he taught. According to the observations of the researcher, all participants are respectful and provided efforts during classes in general. These qualities observed by the researcher were corroborated by the instructors of other courses $(\mathrm{N}=23)$ and a group of 25 individuals was selected based on these qualities. Each participant in the second group was asked whether they would participate in a game organization held in an astro pitch for two weeks without any cost and 12 volunteers were included in the study. 12 of the 14 participants were students (School of Physical Education and Sports) who were selected by this method and the other 2 were research assistants employed at the university with no prior information of this study. These 2 research assistants were also the team captains and selected the teams.

\subsection{Data Collection and Analysis}

Semi-structured interview technique (a qualitative technique) was used during data collection. While the games continued (they are still going on), the participants were first informed about serious leisure activities and they were asked whether this organization was considered as a serious leisure activity by them. Later, the researcher prepared a theoretical framework to ask participants how the organization was born, how it continued non-stop with the same participants and the general benefits of this organization. The main ideas obtained by the researcher were analyzed in terms of content by using Maxqda program and codes, categories and themes were obtained. In addition; Peer debriefing was used to increase the validity of the data. This strategy is achieved through the fact that experienced researchers in qualitative analysis and recreation issues a few interview texts and discusses the coding process to control the emerging themes and codes. Pseudonyms (Beckham, Zidane and Ronaldo for The LosGalacticos; Hulk, Thor and Iron Man for The Avangeres) used instead of coding names when referring to participants in the findings.

\section{Findings}

The code, category and themes obtained from the first question regarding whether they considered themselves as serious leisure participants in this activity are presented in Table 1.

Table 1. Findings on whether the participants were serious leisure participants

\begin{tabular}{|c|c|c|c|c|}
\hline Descriptive Category & Sub Category & & Codes & Definition of the codes \\
\hline \multirow{4}{*}{$\begin{array}{l}\text { Serious leisure time } \\
\text { participation }\end{array}$} & \multirow{4}{*}{ *Characteristics } & $\checkmark$ & Creating a social world & $\begin{array}{ll}* & \text { Spending time with friends } \\
\text { Feelings responsible towards } \\
\text { friends }\end{array}$ \\
\hline & & $\checkmark$ & Determination -Effort & $\begin{array}{ll}\text { Delays } \\
\text { Making it a priority } \\
\text { Feelings of excitement } \\
\text { Need to discuss games }\end{array}$ \\
\hline & & $\checkmark$ & Making a career & $\begin{array}{l}* \text { Developing technique-tactics } \\
\text { Conditioning }\end{array}$ \\
\hline & & $\checkmark$ & Bond & $\begin{array}{ll}* & \text { Continuity } \\
* & \text { Part of the team }\end{array}$ \\
\hline
\end{tabular}

reasons

According to the results of the analysis, the participants made efforts for the activity and tried to associate it with a career. It was also seen that there was a bond between the activity and the participants. In addition, participants created a social world through these activities. Some of the answers provided by the participants for the first question are as follows;

Thor; «Nobody can stop me from going to that game on Monday evenings, my mother and father visited me on Mondays but I still went to the game; my friends arranged to go to the cinema on Mondays but I still went to the game; I argued with my girlfriend many times to go to these matches » 
Ronaldo; «I agree because I feel responsibility towards my friends and instructor, all of us are parts of this team and if I am not there, there may be no games or the game can be lost because of me. I won't do that to my friends》.

According to participants; the benefits of serious leisure activities they observed can be grouped into two sub categories: social and personal benefits. While social benefit category was generally related to friendships and communication codes, the codes associated with personal benefits were pleasure, health and self-realization. Findings related to benefits are shown in Table 2

Table 2. Findings related to benefits of the activity

\begin{tabular}{|c|c|c|c|}
\hline Descriptive Category & Sub Category & Codes & Definition of the codes \\
\hline \multirow{5}{*}{ Benefits } & \multirow{2}{*}{ *Social } & $\checkmark \quad$ Friendship & $\begin{array}{ll}* & \text { Increase in number of friends } \\
& \text { Knowing friends more closely } \\
& \text { Group success }\end{array}$ \\
\hline & & $\checkmark$ Communication & $\begin{array}{l}* \text { Learning new approaches } \\
\quad \text { Feelings of respect } \\
\text { Patience }\end{array}$ \\
\hline & \multirow{3}{*}{ *Personal } & $\checkmark \quad$ Pleasure/enjoyment & $\begin{array}{ll}* & \text { Satisfaction } \\
* & \text { Fun/entertainment }\end{array}$ \\
\hline & & $\checkmark \quad$ Self-realization & $\begin{array}{ll} & \text { Increase in skills } \\
& \text { Increase in competence } \\
\text { Awareness } \\
\text { Feelings of achievement }\end{array}$ \\
\hline & & $\checkmark \quad$ Health & $\begin{array}{ll}* & \text { Increase in condition } \\
* & \text { Strength/Empowerment }\end{array}$ \\
\hline
\end{tabular}

Some participant responses about the benefits of the activity are provided below:

Beckham; «When the games started, I and Hasan only said hello to each other, as the games continued, our friendship grew stronger and now we are roommates, all my teammates have become just like my brothers thanks to these games »

Hulk; «I am very happy when we win, and when we lose I feel really depressed. Whether we win or lose, it definitely affects my normal life»

Finally, the participants were asked how they were able to participate in these activities without interruption and the basic reason why these activities became a part of their lives. In fact, the answer to this question also demonstrates how the participants became serious leisure participants for this activity. The responses of participants to this question are shown in Table 3. "Leader, enjoyment and rapport" emerge as the cub categories of the third question.

Table 3. How come do the activities continue this long? How have they become a part of your life?

\begin{tabular}{|c|c|c|c|c|}
\hline Descriptive Category & $\begin{array}{c}\text { Sub } \\
\text { Category }\end{array}$ & & Codes & Definition of the codes \\
\hline \multirow{5}{*}{$\begin{array}{l}\text { Reasons why the games } \\
\text { continued }\end{array}$} & \multirow{2}{*}{ * Leader } & $\checkmark$ & Responsibility & $\begin{array}{l}\text { Towards instructor } \\
\text { Towards team }\end{array}$ \\
\hline & & $\checkmark$ & Respect & $\begin{array}{l}\text { Towards opponent team } \\
\text { Towards instructors }\end{array}$ \\
\hline & \multirow{2}{*}{ * Enjoyment } & $\checkmark$ & Ambition & $\begin{array}{l}* \text { Desire to win-motivation } \\
* \quad \text { Quality game }\end{array}$ \\
\hline & & $\checkmark$ & Fun/entertainment & $\begin{array}{ll} & \text { Enjoying the game } \\
& \text { Knowledge about the game }\end{array}$ \\
\hline & * Rapport & $\checkmark$ & Friendship & $\begin{array}{l}\text { Respect-being respected } \\
\text { acceptance } \\
\text { Togetherness }\end{array}$ \\
\hline
\end{tabular}

Some of the responses provided by the participants are given below:

Zidane; «If we did not have an instructor with us, I may not have gone to the games this regularly. At first I went to the games so as not to offend the instructor but then there was no need for the instructor to push me (to go the games)»;

Iron Man; «I really like my friends in my team and in the opponent team and o want to spend time with them; beyond the games; I like being with them».

\section{Result}

When the findings are examined in terms of serious leisure perspective; the characteristics of the participant group are similar to the distinctive characteristics of serious leisure participants (Stebbins, 2009; 2012a; 2007; Isik, 2017).

In terms of the benefits of serious leisure, the findings of this study are parallel to those found in many studies in literature on serious leisure perspective (Aitchison, 2003; Dattilo \& Schleien, 1994; Driver, Brown, \& Peterson, 1991; 
Galambos, Lee, Rahn, \& Williams, 1994; Prescott, 1994; Pegg \& Compton, 2003; Stumbo \& Pegg, 2004).

Literature review shows that there are many reasons that affect the participation of individuals in leisure time (Ardahan, Turgut, \& Kaplan Kalkan, 2016). These reasons can be listed as age, gender, income level, urbanization, time and people's desires and expectations. In this study, the reasons for participation in serious leisure should not be considered apart from the reasons that affect leisure time participation in literature. However, the fact that the activity becomes serious and continuous depends on the characteristics of the activity and the group participants.

\section{Discussion}

According to themes found in this study; a leader is required for the participants to be a serious leisure participants and to sustain the activity; the activity should include opportunities for the individual to stand out, there must be rapport in the group, and the activity should be enjoyed.

In terms of the general benefits of serious leisure participation, this study provides important clues as to how individuals can be serious leisure participants. Both social media and mass media tools and activities can be used to both create serious leisure participants and to sustain their participation. This study was designed by the researcher and the ethnographic aspects of the participants contributed to the continuity and realization of the research. By similar methods, further studies can investigate in detail how to be serious leisure participants.

\section{References}

Aitchison, C. (2003). From leisure and disability to disability leisure: Developing data, definition and discourses. Disability and Society 18:955-69. https://doi.org/10.1080/0968759032000127353

Akyildiz, M. (2013). Ciddi ve Kayıtsız Katılımcıların Kişilik Özellikleri ile Boş Zaman Tatmini ve Yaşam Tatmini Arasındaki İlişki. Doktora Tezi, Anadolu Üniversitesi Sağlık Bilimleri Enstitüsü, Eskişehir.

Ardahan, F., Turgut, T., \& Kaplan, K. A. (2016). Her yönüyle rekreasyon. Detay Yayıncılık. Ankara.

Barbieri, C., \& Sotomayor, S. (2013). Surf travel behavior and destination preferences: An application of the serious leisure inventory and measure. Tourism Management, 35, 111-121. https://doi.org/10.1016/j.tourman.2012.06.005

Dattilo, J., \& Schleien, S. J. (1994). Understanding leisure services for individuals with mental retardation. Mental Retardation, 32(1), 53-59.

Driver, B. L., Brown, P. J., \& Peterson, G. L. (1991). Benefits of leisure. In Preliminary drafts of the chapters in this volume were presented at a workshop of the authors in Snowbird, Utah, May 1989. Venture Publishing.

Flack, W. F. (2006). Peripheral feedback effects of facial expressions, bodily postures, and vocal expressions on emotional feelings. Cognition and Emotion, 20, 177-195. https://doi.org/10.1080/02699930500359617

Galambos, L., Lee, R., Rahn, P., \& Williams, B. (1994). The ADA: getting beyond the door. Parks \& Recreation (Arlington), 29(4), 66-71.

Godbout, J. (1990). La Participation: Instrument de Professionnalisation des Loisirs. Loisir et Societe/Sciety and Leisure, 9, 33-40. https://doi.org/10.1080/07053436.1986.10715249

Hamilton-Smith, E. (1993). In the Australian bush: Some reflections on serious leisure. World Leisure \& Recreation, 35(1), 10-13. https://doi.org/10.1080/10261133.1993.10559134

Harrison, D. (2001). Less developed countries and tourism: The overall pattern. Tourism and the less developed world: issues and case studies, 1-22. https://doi.org/10.1079/9780851994338.0001

Haworth, J. T. (1986). Meaningful activity and psychological models of non-employment. Leisure Studies, 5(3), 281-297. https://doi.org/10.1080/02614368600390211

Heuser, L. (2005). We're not too old to play sports: The career of women lawn bowlers. Leisure studies, 24(1), 45-60. https://doi.org/10.1080/0201436042000250131

Hutchinson, S. L., \& Kleiber, D. A. (2005). Gifts of the ordinary: Casual leisure's contributions to health and well-being. World Leisure Journal, 47(3), 2-16. https://doi.org/10.1080/04419057.2005.9674401

Isik, U. (2017). The Role of Serious Leisure Participation and Hearing Impairment in Recognising Different Emotions (With Dimensions of Personality and Emotional Intelligence). Dumlupinar University Graduate School of Health Sciences, Department of Physical Education and Sports, PhD Thesis, Kutahya.

Kim, J., Dattilo, J., \& Heo, J. (2011). Taekwondo participation as serious leisure for life satisfaction and Health, Journal of Leisure Research, 43(4). https://doi.org/10.1080/00222216.2011.11950249

Kleiber, D. A. (1999). Leisure experience and human development: A dialectical interpretation. Basic Books, Inc.

Mannell, R. C. (1993). High-investment activity and life satisfaction among older adults: Committed, serious leisure, 
and flow activities.

McBrearty, S., \& Stringer, C. (2007). Palaeoanthropology: The coast in colour. Nature,449(7164), 793. https://doi.org/10.1038/449793a

Patterson, I. (2000). Developing a meaningful identity for people with disabilities through serious leisure activities. World Leisure Journal, 42(2), 41-51. https://doi.org/10.1080/04419057.2000.9674185

Patterson, I. (2001). Serious leisure as a positive contributor to social inclusion for people with intellectual disabilities. World Leisure Journals, 3, 16-24. https://doi.org/10.1080/04419057.2001.9674234

Patterson, I., \& Pegg, S. (2009). Serious leisure and people with intellectual disabilities: Benefits and opportunities. Leisure Studies, 28(4), 387-402. https://doi.org/10.1080/02614360903071688

Pegg, S., \& Compton, D. M. (2003). Creating opportunities and ensuring Access to leisure and recreation services though Inclusion in the Global Community. Leisure/Loisir, 28(1-2), 5-26. https://doi.org/10.1080/14927713.2003.9649937

Prescott, G. E. (1994). Leisure as a vocational option for people with disabilities. Leisure Options: The Australian Journal of Leisure and Recreation, 4, 18-23.

Roberson Jr, D. N. (2005). Leisure and learning: An investigation of older adults and self-directed learning. Leisure/Loisir, 29(2), 203-237. https://doi.org/10.1080/14927713.2005.9651330

Roker, D., Player, K., \& Coleman, J. (1998). Challenging the image: The involvement of young people with disabilities in volunteering and campaigning. Disability \& Society, 13(5), 725-741. https://doi.org/10.1080/09687599826489

Shen, X. S., Yarnal, C. (2010). Blowing open the serious leisure-casual leisure dichotomy: What's in there?, Leisure Sciences, (32), 162-179. https://doi.org/10.1080/01490400903547179

Stebbins, R. A. (1980). "Amateur" and "Hobbyist" as concepts for the study of leisure problems, Social Problems, 27(4), 413-417. https://doi.org/10.2307/800168

Stebbins, R. A. (1993). Social world, life-style, and serious leisure: Toward a mesostructural analysis. World Leisure and Recreation, 35(Spring), 23-26. https://doi.org/10.1080/10261133.1993.10559137

Stebbins, R. A. (1997). Casual leisure: A conceptual statement, Leisure Studies, 16, 17-25. https://doi.org/10.1080/026143697375485

Stebbins, R. A. (2001). The costs and benefits of hedonism: Some consequences of taking casual leisure seriously. Leisure studies, 20(4), 305-309. https://doi.org/10.1080/02614360110086561

Stebbins, R. A. (2005). Choice and Experiential Definitions of Leisure. Leisure Sciences, 27(4), 349-352. https://doi.org/10.1080/01490400590962470

Stebbins, R. A. (2007). Serious leisure: A perspective for our time (Vol. 95). Transaction Publishers.

Stebbins, R. A. (2009). Leisure and consumption: Common ground/separate worlds. Springer. https://doi.org/10.1057/9780230244863

Stebbins, R. A. (2012a). Comment on Scott: Recreation Specialization and the CL-SL Continuum. Leisure Sciences, 34(4), 372-374. https://doi.org/10.1080/01490400.2012.687646

Stebbins, R. A. (2012b).Unpaid Work of Love: Defining the Work-Leisure Axis of Volunteering, Leisure Studies, 1-7.

Stumbo, N. J., \& Pegg, S. (2004). Choices and challenges: Physical activity and people with disabilities. Annals of Leisure Research, 7(2), 104-126. https://doi.org/10.1080/11745398.2004.10600945

Sylvester, C. (1999). The classical idea of leisure: Cultural ideal or class prejudice?. Leisure Sciences, 21(1), 3-16. https://doi.org/10.1080/014904099273255

Wearing, S. (2004). Examining best practice in volunteer tourism. Volunteering as leisure/leisure as volunteering: An international assessment, 209-224. https://doi.org/10.1079/9780851997506.0209

Weiler, B., \& Hall, C. M. (1992). Special interest tourism: in search of an alternative. Special interest tourism: in search of an alternative, 199-204.

\section{Copyrights}

Copyright for this article is retained by the author(s), with first publication rights granted to the journal.

This is an open-access article distributed under the terms and conditions of the Creative Commons Attribution license which permits unrestricted use, distribution, and reproduction in any medium, provided the original work is properly cited. 